\title{
Reflexões Sobre a Política Nacional de Humanização e Os Desafios de Sua Implantação Num Centro de Saúde
}

\author{
Pereira, Paula Bertoluci Alves; Sundfeld, Ana Cristina \\ Faculdade de Saúde Pública - USP — paulabertoluci@yahoo.com.br
}

\begin{abstract}
Introdução: a Política Nacional de Humanização (PNH) aposta na transversalidade das práticas de atenção e de gestão do Sistema Único de Saúde, no combate ao desgaste do campo da saúde, em tensão com os interesses do capitalismo, que submete o cuidado aos cálculos do custo e do lucro. Sob tal lógica materialista, muitas vezes a relação entre trabalhador e usuário foi se consolidando de modo hierarquizado, uma ação sobre o outro, esvaziada de interesse numa escuta singular. o trabalho em saúde, permeado por segmentações entre saberes e práticas, contribui para reforçar o distanciamento entre profissionais e a abordagem reducionista do usuário, geralmente "fatiado" dentro dos serviços. Estes ingredientes contribuem para um cuidado precário, alheio à autonomia do usuário. a $\mathrm{PNH}$ propõe a transformação das relações, a criação de modos de interação abertos ao encontro com a diferença, aos interesses e singularidades capazes de potencializar o protagonismo e a pactuação do cuidado. Esta criação no terreno da micropolítica dos serviços pode colaborar para relações comprometidas com a coresponsabilização entre trabalhadores e usuários, desfazendo a verticalidade das ações e orientações prescritivas. no lugar do poder sobre o outro, a expressão de múltiplas vozes, com espaço para produções vivas de governabilidade. Neste sentido, a política de humanização investe em atitudes ético-estético-políticas que possam inaugurar valores, criar laços com as diferenças que habitam a dimensão do coletivo em convivência na pólis, com as tensões e exercícios de poder que permeiam a democracia, onde nenhuma vida pode valer mais do que outra. Objetivo: Refletir sobre o processo de trabalho em um centro de saúde misto e as dificuldades para a concretização do cuidado em ressonância com os princípios propostos pela PNH. Metodologia: Revisão de literatura e observação participante em um centro de saúde misto entre setembro de 2010 a dezembro de 2013. Resultados: Durante este período foram realizadas tentativas pontuais pela gestão para a instituição de espaços de educação permanente no serviço, entretanto com baixa adesão e pouca problematização sobre o processo de trabalho e a produção do cuidado pelos participantes. a produção de cuidado por meio da construção de encontros dialógicos, bem como a elaboração de um plano terapêutico singular ficam a cargo de cada trabalhador. Conclusão: a inexistência de dispositivos de fomento à cogestão e inclusão de gestores, trabalhadores e usuários no processo de produção de saúde continua reforçando modos de atenção automatizados que fortalecem o olhar sobre a doença e não reconhecem o usuário enquanto sujeito e protagonista do ato de saúde. a PNH coloca como tarefa substantiva a construção de relações que alterem a dinâmica do trabalho, mas não deve ser compreendida como a vontade particular de um sujeito, exigindo ação transdisciplinar e intersetorial para a produção de subjetividade e autonomia dos sujeitos envolvidos.
\end{abstract}

Pereira, Paula Bertoluci Alves; Sundfeld, Ana Cristina. Reflexões Sobre a Política Nacional de Humanização e Os Desafios de Sua Implantação Num Centro de Saúde. In: Anais do Congresso Internacional de Humanidades \& Humanização em Saúde [= Blucher Medical Proceedings, num.2, vol.1]. São Paulo: Editora Blucher, 2014. ISSN 2357-7282

DOI 10.5151/medpro-cihhs-10296 